\title{
Assessment and Measurement of Atmospheric Pollution (Particulate Matter) Around Zawiya City-Libya
}

\author{
Busheina IS ${ }^{1}$, Kammashi $\mathbf{M}^{2}$, Etorki AM ${ }^{{ }^{*}}$ and EL-Rouissi RH ${ }^{1}$
}

${ }^{1}$ Department of Chemistry, University of Zawia, Zawia, Libya

${ }^{2}$ Department of Chemistry, University of Tripoli, Tripoli, Libya

\begin{abstract}
Total air suspended particulates (TSP) samples were collected over glass fiber filter and determined gravimetrically. The contents on the glass filter was digested in $\mathrm{HF}-\mathrm{HCl}-\mathrm{HNO}_{3}$ mixture and the trace elemental analysis of $\mathrm{Al}, \mathrm{Fe}, \mathrm{Mn}$, and $\mathrm{Pb}$ were performed using Inductively Coupled Plasma Optical Emission Spectrometry (ICP-OES) technique, which offers many advantages such as low detection limits, wide linear calibration range and no matrix interference in addition to simultaneous multi-element determination. The filter with TSP was weighted, dissolved in $\mathrm{HF}-\mathrm{HCl}-\mathrm{HNO}_{3}$ acid mixture and the trace element such as $\mathrm{Al}, \mathrm{Fe}, \mathrm{Mn}$ and $\mathrm{Pb}$ were determined using (ICP-OES) technique.

This work was carried out at four sites around Zawia city. Three sampling location were selected on sites of heavy traffics and industrial activities. These sites were $\left(A_{1}\right)$ at the center of Zawia city; $\left(A_{2}\right)$ near the power station and the refinery; $\left(A_{3}\right)$ nearby the main coastal road and $\left(A_{4}\right.$ control) at zone where there are no industrial activities or any obvious source of pollution. These samples were collected during Summer, Autumn, Spring, and Winter. The daily variation of TSP during this period showed the lowest value $70 \mu \mathrm{g} / \mathrm{m}^{3}$ in January (Winter), and the highest value $587.121 \mu \mathrm{g} / \mathrm{m}^{3}$. This value is relatively high compared with EU limit values $\left(300 \mu \mathrm{g} / \mathrm{m}^{3}\right)$, USEPA $\left(150 \mu \mathrm{g} / \mathrm{m}^{3}\right)$, and WHO $(150-230 \mu \mathrm{g} /$ $\mathrm{m}^{3}$ ). The mean monthly variation of TSP showed the lowest measured result of $78.28 \pm 0.08 \mu \mathrm{g} / \mathrm{m}^{3}$ in January and the highest value $306 \mu \mathrm{g} / \mathrm{m}^{3}$ in May. Seasonal variation of TSP showed high results during Spring season which is 239.44 $\mu \mathrm{g} / \mathrm{m}^{3}$ and all other seasons showed lower values of $131.19 \mu \mathrm{g} / \mathrm{m}^{3}, 198.28 \mu \mathrm{g} / \mathrm{m}^{3}$ and $159.85 \mu \mathrm{g} / \mathrm{m}^{3}$ for Winter, Autumn, and Summer, respectively compared with Spring season. The trace elements levels in TSP were Al>Fe $>\mathrm{Pb}>\mathrm{Mn}$. The concentration of $\mathrm{Al}, \mathrm{Fe}, \mathrm{Mn}$ and $\mathrm{Pb}$ are lower in site $\mathrm{A}_{4}$ and $\mathrm{A}_{1}$ and higher in sites $\mathrm{A}_{3}$ and $\mathrm{A}_{2}$ due to heavy traffic and industrial activities. The meteorological parameters over the study area showed some factors such as wind speed, humidity and temperature that may affect TSP concentrations.
\end{abstract}

Keywords: Atmospheric pollution; Heavy metals in air; TSP; SPM

\section{Introduction}

Due to the lack of TSP data in the ambient air around Zawia city, this experimental work provides a database of TSP and trace elements such as $(\mathrm{Al}, \mathrm{Fe}, \mathrm{Mn}, \mathrm{Cu}$, and $\mathrm{Pb})$. Suspended particulate matter $(\mathrm{SPM})$ is one of the most important atmospheric pollutants due to their adverse effect on human health, plants and aquatic life. The environmental materials of atmospheric particles are polluted due to the presence of heavy metals in their composition [1-4]. Recently, it has been that found particulate matter from air pollution is linked to autism [5].

Atmosphere suspended particulate matter (SPM) can be divided to airborne solid and low vapor pressure liquefied particles having aerodynamic particle sizes from below 0.01 up to $100 \mu \mathrm{m}$ [6,7]. Particles can be also classified by their physical state; which is a measure of density and shape, to three sizes range (coarse, fine and ultrafine) (or PM10, PM2.5, and PM by the U. S. Environmental protection Agency, U. S. EPA).

The atmospheric lifetime of total suspended particulates (TSP) is related to the particle size. Larger particles ( $10 \mu \mathrm{m}$ diameter) may be airborne for up to $20 \mathrm{~h}$ and may travel $20-30 \mathrm{~km}$ while smaller particles may travel several thousand kilometers [8]. Large particles tend to settle out of the air quicker than smaller particles which remain suspended in the atmosphere for extended periods [9].

Total suspended particulate (TSP) in the ambient atmosphere can arise from a wide variety sources, forest fires, sea spry, volcanic emission, dust storms, soil and rock erosion, [10-12]. Natural sources, like dust, generally contribute aerosols of sizes $>10 \mu \mathrm{m}$ in diameter, while anthropogenic sources contribute $<10 \mathrm{pm}$ (classified under PM10 sized aerosols) [13]. The TSP concentration from natural origin is lower than $10 \mu \mathrm{g} / \mathrm{m}^{3}$. The natural sources that have the greatest impact on the TSP concentrations include suspended terrestrial dust, sea salt spray (mainly at coastal sites) and biomass burning (forest fires) [14], and the major sources of anthropogenic or man-made, particles include transportation, stationary combustion, space heating, biomass burning, and industrial and traffic-related fugitive emissions (street dust) [14].

Resent reports have showed the impact of atmospheric pollutants on health when they are present in relatively high concentrations of TSP [15-19]. In adults, SP exposure is also associated with increased incidence of respiratory symptoms, transient decrements in pulmonary function levels, and the onset of chronic pulmonary disease in adults [10]. Fine particles $(<2.5 \mu \mathrm{m}$ in diameter $)$ are thought to be more dangerous because of the ability to penetrate deeper into lung tissue leading to blockage of the very small passages in the lungs and, therefore, are especially important in the absorption of heavy metals and other toxic contaminants [18-20].

Moreover, particulate materials also can effect vegetation and ecosystem (visibility) and can cause damage to paint and building materials. The effects on vegetation include reduced growth and productivity due to interference with plant photosynthesis and

*Corresponding author: Etorki AM, Department of Chemistry, University of Tripoli, Tripoli, Libya, Tel: +218927402789; Fax: +218213342935; E-mail: a.etorki@uot.edu.ly

Received May 12, 2017; Accepted May 19, 2017; Published June 12, 2017

Citation: Busheina IS, Kammashi M, Etorki AM, EL-Rouissi RH (2017) Assessment and Measurement of Atmospheric Pollution (Particulate Matter) Around Zawiya CityLibya. J Environ Anal Toxicol 7: 473. doi: 10.4172/2161-0525.1000473

Copyright: ( 2017 Busheina IS, et al. This is an open-access article distributed under the terms of the Creative Commons Attribution License, which permits unrestricted use, distribution, and reproduction in any medium, provided the original author and source are credited. 
Citation: Busheina IS, Kammashi M, Etorki AM, EL-Rouissi RH (2017) Assessment and Measurement of Atmospheric Pollution (Particulate Matter) Around Zawiya City-Libya. J Environ Anal Toxicol 7: 473. doi: 10.4172/2161-0525.1000473

Page 2 of 4

phytotoxic impacts. Visibility impairment is effected by the scattering and absorption of light by atmospheric aerosols, particularly those of $<2.5 \mu \mathrm{m} \mid 13$ ]. Buildings and materials are negatively affected through increased rates of corrosion, erosion, soiling and discoloration [18] Chemical and physical compositions of total suspended particulates (TSP) depending on the location, time of year, and weather [21]. Trace elements such as $\mathrm{Al}, \mathrm{Pb}, \mathrm{Mn}$ and $\mathrm{Fe}$ are among the important natural and anthropogenic constituents of TSP [22].

\section{Experimental}

\section{Reagents}

MilliQ deionized water was used in all experiments: All chemicals used in this study were analytical grade; Nitric acid $(70.5 \mathrm{w} / \mathrm{w} \%$ BDH), hydrochloric acid (36 w/w\%, Breckland Scientific Suppliers), Hydrofluoric acid (47 w/w\%, India), formaldehyde (37 w/w\%, RiedelDehaen AG. Seeizel) and Phosphoric acid, $\mathrm{H}_{3} \mathrm{PO}_{4}$, (85 w\%, Merck). Mercuric chloride $\left(\mathrm{HgCl}_{2}\right)$ and $\mathrm{Na}_{2}$ EDTA (Breckland Scientific Supplies), potassium chloride (BDH), sulfamic acid and sodium bisulfite ( $>58.5 \% \mathrm{~m}$ Sigma) and pararosanilinic acetate (PRA) technical dyes HN. Metal standard stock solutions prepared from ultra-high purity grade chemicals ( $99 \%$ pure or greater).

\section{Instrumentation}

Total suspended particulate samples were collected in a sampling train consisting pump, drying tube, filter holder, and membrane filters (0.8 micrometer). The flow rate of the pump (Knf Neuberger Model D-79112 freibrg) was calibrated by flow rate measurement devices (Analis BELGIUM). The Mass of TSP samples were determined using a Mettler-Toledo sensitive of the balance (Model AG 204 and $0.1 \mathrm{mg}$ sensitivity). TSP samples were analyzed for, $\mathrm{Al}, \mathrm{Fe}, \mathrm{Mn}$, and $\mathrm{Pb}$ by using (ICP-OES) instrument, Model (EL04123360) VISTA-PRO CCD simultaneous ICP-OES (Libyan Petroleum Institute).

\section{Methods}

Sampling stations and location: Four Sampling sites $\left(A_{1}, A_{2}, A_{3}\right.$ and $\mathrm{A}_{4}$ ) around Zawia city were slected. Three sites were selected were heavy traffics and industrial activities. $A_{1}$ is at city center; $A_{2}$ is near the power station, and $\mathrm{A}_{3}$ is on the main road. $\mathrm{A}_{4}$ is located at a zone with no industrial activities or any obvious source of pollution.

Sample collection: TSP samples were filtered on $0.8 \mu \mathrm{m}$ membrane filters, by drawing air valve at the rate of $1.0 \mathrm{~L} / \mathrm{min}$ flow rate using a lowvolume sampler with the filter head being at $3 \mathrm{~m}$ above the ground air is drown into a covered housing and through a filter by means of high-flow rate blower, that allows suspended particles having diameters 1-100 $\mu \mathrm{m}$ to be filtered on filters (during day light and an average of about $24 \mathrm{~h}$ sampling time). After sample collection completed, filters were put back into their containers and stored in a dark cold place until analysis were performed.

Digestion procedure: Prior to ICP-OES analysis it was necessary to dissolve the particulate matter collected on the filter and weighted. The sample was digested in Poly tetrafluoroethylene (PTFE) container with 5 $\mathrm{ml}$ of hydrofluoric acid, $5 \mathrm{ml}$ nitric acid, and $5 \mathrm{ml}$ hydrochloric acid and heating for $1.0 \mathrm{~h}$. The mixture was evaporated to dryness. The residue was dissolved by heating gently in $20 \mathrm{ml}$ of $0.5 \mathrm{~mol} / \mathrm{l}$ hydrochloric acid and filtered. The filtrate was diluted to $50 \mathrm{ml}$ with $0.5 \mathrm{~mol} / \mathrm{l}$ hydrochloric acid and stored in a dark and cold place $\left(4^{\circ} \mathrm{C}\right)$ until analysis was performed [23].

\section{Results and Discussion}

\section{TSP concentrations}

In this study, total suspended particulate (TSP) samples were collected for determining their concentration in the atmosphere around Zawia city and an attempt to establish a local TSP database as a part of environmental data base for Libya. The ambient air quality standards for total suspended particulate matter are $75 \mu \mathrm{g} / \mathrm{m}^{3}$ annual geometric mean, and $150 \mu \mathrm{g} / \mathrm{m}^{3}$ maximum. National Ambient Air Quality Standards (NAAQS) was shown in Table 1 [24], while WHO advises that concentration of TSP in air should not exceed the annual average of $60-90 \mu \mathrm{g} / \mathrm{m}^{3}$. The ambient air quality standards for PM 2.5 particulate matter are $15 \mu \mathrm{g} / \mathrm{m}^{3}$, annual arithmetic mean concentration; and $65 \mu \mathrm{g} /$ $\mathrm{m}^{3}[24]$.

The analytical results for TSP that summarized in Table 1 ranged from 70.0 to $587.121 \mu \mathrm{g} / \mathrm{m}^{3}$. The value $70.0 \mu \mathrm{g} / \mathrm{m}^{3}$ was in January (Winter), and the value $587.121 \mu \mathrm{g} / \mathrm{m}^{3}$ was in May (Spring) this value is relatively high compared with EU limit values $300 \mu \mathrm{g} / \mathrm{m}^{3}$, USEPA (150 $\left.\mu \mathrm{g} / \mathrm{m}^{3}\right)$, and WHO $\left(150-230 \mu \mathrm{g} / \mathrm{m}^{3}\right)$.

Average monthly variation of TSP over study area $\left(\mathrm{A}_{4}\right)$ during Summer (June-August) is shown in Table 2. The monthly variation of this season shows a high value $204.8 \mu \mathrm{g} / \mathrm{m}^{3}$ in June compared with August and July. Also, the average wind speed showed a high value of 6.7 Knots in this month (June). The temperature and humidity were relativity the same in the three months of this season (Figure 1). Monthly variation of TSP over study area $\left(\mathrm{A}_{3}\right)$ during Autumn (September-November) is shown in Table 3 . The monthly variation of this season shows a high value $248.9 \mu \mathrm{g} / \mathrm{m}^{3}$ in September compared with October and November. Also the average temperature and wind speed showed a high value $27^{\circ} \mathrm{C}$ and 5.6 Knots respectively in this month (September). The humidity relative during the three months of this season is similar (65\%) (Figure 2).

Average monthly variation of TSP over study area (A2, A1) during Spring (March-May) is shown in Table 3. The monthly variation of this season showed a higher value $\left(306.0 \mu \mathrm{g} / \mathrm{m}^{3}\right)$ in the month of May, compared with March and April. Also the average temperature and the average wind speed showed higher value $24^{\circ} \mathrm{C}$ and $7.8 \mathrm{~m} / \mathrm{s}$ respectively in this month (May), while humidity showed a higher value of $63 \%$ in May (Table 3).

Average monthly variation of TSP over study area (A4) during Winter (December-February) is shown in Table 3. The monthly variation of this season shows a high value $177.39 \mu \mathrm{g} / \mathrm{m}^{3}$ in February compared with December and January. Also the average wind speed showed a higher value $5.8 \mathrm{~m} / \mathrm{s}$ in this month (February).

\begin{tabular}{|c|c|c|c|}
\hline \multirow{2}{*}{ standard or guideline } & \multicolumn{2}{|c|}{ long-term (annual) } & \multicolumn{2}{|c|}{ short-term (24 h) } \\
\cline { 2 - 4 } & PM $_{10}$ & 150 & \multicolumn{1}{|c|}{ PM $_{10}$} \\
\hline EU limit values & - & 57 & 150 \\
\hline WSEPA primary and secondary standards & 50 & $60-90$ & 25 \\
\hline WHO guidelines & 10 & 70 & 25 \\
\hline
\end{tabular}

Sources: European Community 2006 (EU); United States, CFR (USEPA); WHO 2005 (WHO Guidelines).

Table 1: Reference standards and guidelines for average ambient particulate concentration (micrograms per cubic meter). 
Citation: Busheina IS, Kammashi M, Etorki AM, EL-Rouissi RH (2017) Assessment and Measurement of Atmospheric Pollution (Particulate Matter) Around Zawiya City-Libya. J Environ Anal Toxicol 7: 473. doi: 10.4172/2161-0525.1000473

Page 3 of 4

\begin{tabular}{|c|c|c|c|c|}
\hline Months & $\mathbf{T S P} \mathbf{\mu g} / \mathbf{m}^{\mathbf{3}}$ & $\mathbf{W} \mathbf{~} / \mathbf{s}$ & $\mathbf{H} \%$ & $\mathbf{T} \mathbf{C}$ \\
\hline Jun-07 & 204.8 & 6.7 & 55 & 28.0 \\
\hline Jul-07 & 128.9 & 5.8 & 68 & 25.3 \\
\hline Aug-07 & 145.8 & 5.5 & 62 & 28.9 \\
\hline Sep-07 & 248.9 & 5.6 & 65 & 27.0 \\
\hline Oct-07 & 183.3 & 5.8 & 65 & 22.5 \\
\hline Nov-07 & 162.6 & 3.9 & 65 & 17.5 \\
\hline Mar-08 & 131.3 & 5.6 & 63 & 16.2 \\
\hline Apr-08 & 280.9 & 6 & 58 & 20.0 \\
\hline May-08 & 306.0 & 7.8 & 55 & 24.7 \\
\hline Dec-08 & 137.9 & 4.7 & 70 & 13.1 \\
\hline
\end{tabular}

Table 2: The average air temperature, average humidity, average wind speed and monthly concentration of TSP samples.

\begin{tabular}{|c|c|}
\hline Sampling point & Mean TSP $\left(\boldsymbol{\mu g} / \mathbf{m}^{3}\right)$ \\
\hline$A_{1}$ & $117.18 \pm 7.73$ \\
\hline$A_{2}$ & $199.49 \pm 2.33$ \\
\hline$A_{3}$ & $131.55 \pm 12.44$ \\
\hline$A_{4}$ & $119.66 \pm 6.09$ \\
\hline
\end{tabular}

Table 3: The mean variation of TSP concentration over the study area.

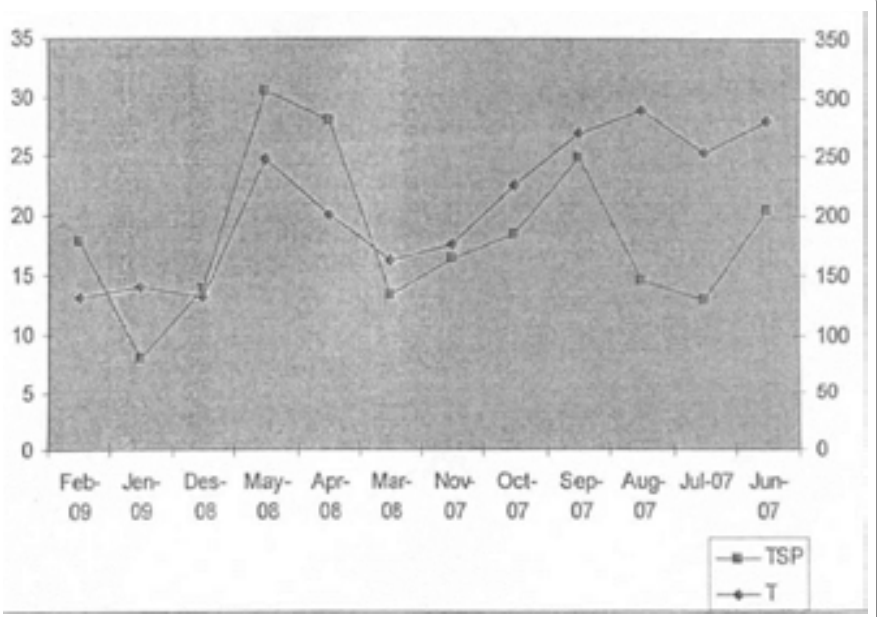

Figure 1: Air temperature and TSP monthly concentrations variation.

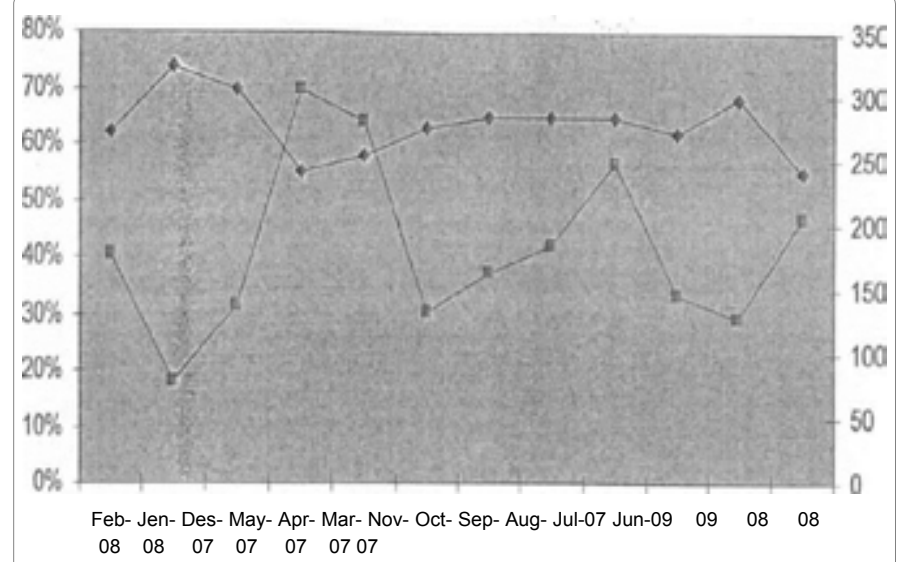

Figure 2: Monthly variation of relative humidity and TSP concentrations.

Table 4 showed the monthly average values of TSP during 2007, 2008 and 2009 over the study area (A1, A2, A3 and A4). The monthly average concentrations of TSP showed a strong peak between July and March. The average air temperature, average humidity, average wind

\begin{tabular}{|c|c|c|c|c|c|}
\hline Size & Seasons & Mean & Max & Min & No.s \\
\hline \multirow{3}{*}{ TSP } & Summer 2007 & 159.85 & 315.65 & 63.13 & 26 \\
\cline { 2 - 6 } & Autumn 2007 & 198.28 & 385.10 & 25.25 & 27 \\
\cline { 2 - 6 } & Spring 2008 & 239.44 & 587.12 & 44.19 & 35 \\
\hline & Winter 2008-2009 & 131.19 & 505.05 & 37.87 & 32 \\
\hline
\end{tabular}

Table 4: Average seasonal mass concentration of TSP $\left(\mu \mathrm{g} / \mathrm{m}^{3}\right)$.

\begin{tabular}{|c|c|c|c|c|}
\hline Site & $\mathbf{A}_{\mathbf{4}}(\mathbf{n}=\mathbf{6})$ & $\mathbf{A}_{\mathbf{3}}(\mathbf{n}=\mathbf{7})$ & $\mathbf{A}_{\mathbf{2}}(\mathbf{n}=\mathbf{6})$ & $\mathbf{A}_{\mathbf{1}}(\mathbf{n}=\mathbf{8})$ \\
\hline $\mathrm{Al} \mathrm{ug} / \mathrm{m}^{3}$ & 4617.15 & 19772.08 & 12789.83 & 714.53 \\
\hline $\mathrm{Fe} \mathrm{ug} / \mathrm{m}^{3}$ & 2220.97 & 4432.21 & 4425.32 & 2527.98 \\
\hline $\mathrm{Mn} \mathrm{ug} / \mathrm{m}^{3}$ & 23.29 & 135.91 & 82.85 & 62 \\
\hline $\mathrm{Pb} \mathrm{ug} / \mathrm{m}^{3}$ & 634.75 & 1615.1 & 2504.94 & 1811.23 \\
\hline
\end{tabular}

Table 5: The levels of $\mathrm{Al}, \mathrm{Fe}, \mathrm{Mn}, \mathrm{Cu}$, and $\mathrm{Pb}\left(\mu \mathrm{g} / \mathrm{m}^{3}\right)$ in TSP samples.

speed and monthly concentration of TSP samples are summarized in Table 2. The mean variation of TSP concentration in study areas (Al, A2, A3, and A4) has been shown in Table 3. The results showed relatively higher values in zone A2 which is $\left(199.49 \mu \mathrm{g} / \mathrm{m}^{3}\right)$.

Seasonal variation of TSP during 2007, 2008 and 2009 over the study area has been shown in Table 2 and Table 5 . The results showed relatively higher values during Spring season which equal to $239.44 \pm$ $2.76 \mu \mathrm{g} / \mathrm{m}^{3}$, other seasons showed less values ranged from $\sim 131.19 \mu \mathrm{g} /$ $\mathrm{m}^{3}$ to $159.85 \mu \mathrm{g} / \mathrm{m}^{3}$.

\section{Elemental concentration}

The levels of trace elements are varying according to the sources of particles [25]. Trace elements are of particular importance due to their potential toxicity for the environment and human being. Metals are non-degradable, and can accumulate in the human body system, causing damage to internal organs and systems [26,27]. Chemical analysis for elements $\mathrm{Al}, \mathrm{Fe}, \mathrm{Mn}$, and $\mathrm{Pb}$ present in the total suspended particulates were analyzed using ICP-OES. The results are shown in Table 4. The results showed that, the concentrations of $\mathrm{Al}, \mathrm{Fe}, \mathrm{Mn}$ and $\mathrm{Pb}$ are low in $\mathrm{A} 1$ and $\mathrm{A} 4$ and high at sites $\mathrm{A} 2$ and $\mathrm{A} 3 . \mathrm{A} 2$ and $\mathrm{A} 3$ areas have heavy traffic and a lot of industrial activities.

The sources of Aluminum in atmospheric samples may include highly contaminated soil derived dusts (clay dust or Aluminum silicate) and nearby agriculture areas. These natural processes far outweigh direct anthropogenic contributions to the environment [27,28]. Long lasting uptakes of significant concentrations of aluminum can lead to serious health effects [29]. Iron is one of the most abundant elements in atmospheric samples. In this study, iron could be introduced into the atmosphere as soil dust and fly ash from Zawya power plants, exhaust of vehicle's combustion engines, and from industrial operations [29]. Iron may cause conjunctivitis, choroiditis, and retinitis if it contacts and remains in the tissues. Chronic inhalation of excessive concentrations of iron oxide dusts may result in development of a benign pneumoconiosis, called siderosis.

In this study, the major sources of atmospheric manganese could be suspension of road dust by vehicles, wind erosion and suspension of soil [30]. Exposure to manganese can affect lung, central nervous system, and some biological indices. The principal effects of longterm occupational exposure to inorganic manganese compounds are "manganese pneumonia" or pneumonitis and, more commonly, manganese. About $90 \%$ of lead in the atmosphere comes from the exhaust gases of motor vehicles, due to the application of lead in fuels. In vehicles engines lead is burned, so that lead salts (chlorides, bromides, and oxides) will originate. The reported lead salts concentrations 
Citation: Busheina IS, Kammashi M, Etorki AM, EL-Rouissi RH (2017) Assessment and Measurement of Atmospheric Pollution (Particulate Matter) Around Zawiya City-Libya. J Environ Anal Toxicol 7: 473. doi: 10.4172/2161-0525.1000473

Page 4 of 4

could have entered the study sites environment through the exhausts of vehicles, from petrol stations dispensing leaded fuel, exhaust from local power station, Zawya oil refinery, the huge area of vehicle scrabs nearby and small amounts in the earth's crust as lead sulfide, lead oxide or lead carbonate. Lead can have the most damaging effects on human health, such as: Disruption of the biosynthesis of hemoglobin, anemia, blood cells miscarriages and subtle abortions. The ambient air quality standard for lead is $1.5 \mu \mathrm{m}$ elemental lead per cubic meter, maximum.

\section{Conclusions}

This study presented analytical data of TSP during the studied periods. From the literature review no data was found. Total suspended particulates content can be variable with location, time of year, and weather conditions with maximum monthly concentration of TSP found to be in May 2008, which is characterized by high wind speed (7.8 knots) compared to other months of the year. The seasonal variation exhibits maximum mean concentration of TSP in Spring $\left(239.44 \mu \mathrm{g} / \mathrm{m}^{3}\right)$ and minimum mean concentration in Winter (131.199 $\mu \mathrm{g} / \mathrm{m}^{3}$ ) due to the characteristic enhanced rain falls which caused the decrease in the TSP concentration. The order of trace elements in TSP was $\mathrm{Al}>\mathrm{Fe}>\mathrm{Pb}>\mathrm{Mn}$. The fluctuations in the concentration levels could be a direct function of emission sources.

\section{References}

1. Tasdemir Y, Kural C, Cindoruk SS, Vardar N (2006) Assessment of trace element concentrations and their estimated dry deposition fluxes in an urban atmosphere. Atmospheric Res 81: 17-35.

2. Sonibare JA, Akeredolu FA, Osibanjo O, Latinwo I (2004) ED-XRF Analysis of Total Suspended Particulates from Enamelware Manufacturing Industry. Am J Appl Sci 1: 295-300.

3. Shah MH, Shaheen N, Jaffar M, Khalique A, Tariq SR, et al. (2005) Spatial variations in selected metal contents and particle size distribution in an urban and rural atmosphere of Islamabad, Pakistan. J Environ Manage 78: 128-137.

4. Sella SM, Netto AD, da Silva Filho EV, Araújo MT, et al. (2004) Short-term and spatial variation of selected metals in the atmosphere of Nitero' i City, Brazil. Microchem J 78: 85-90.

5. Raz R, Roberts AL, Lyall K, Hart JE, Just AC, et al. (2015) Autism Spectrum Disorder and Particulate Matter Air Pollution before, during, and after Pregnancy: A Nested Case-Control Analysis within the Nurses' Health Study II Cohort. Environ Health Perspec 13: 264-270.

6. Balaceanv C, Stefan S (2004) The assessment of the total particulate matter in the urban ambient air. Romanian Reports in Physics 56: 757-768.

7. Choi JC, Lee M, Chun Y, Kim J, Oh S (2001) Chemical composition and source signature of spring aerosol in Seoul, Korea. J Geophys Res 106: 18067-18074.

8. Case MW, Williams R, Yeatts K, Chen FL, Scott J, et al. (2008) Evaluation of a direct personal coarse particulate matter monitor. Atmospheric Enviro 42 : 4446-4452.

9. Brunekreef B, Maynard RL (2008) A note on the $2008 \mathrm{EU}$ standards for particulate matter. Atmospheric Environ 42: 6425-6430.

10. Neas LM (2000) Fine particulate matter and cardiovascular disease. Fue Process Technol 65: 55-67.

11. Wu YF, Liu CQ, Tu CL (2008) Atmospheric Deposition of Metals in TSP of Guiyang, PR China. Bull Environ Contam Toxicol 80: 465-468.
12. Kulkami MM, Ppatil RS (2003) Personal Exposure to Toxic Metals Indian Metropolitan Region. IE Journal-EN 84: 23-29.

13. National Research Council (1993) Protecting Visibility in National Parks and Wilderness Areas. National Academy Press, Washington, DC, 446.

14. Stefánsson A, Gunnarsson I, Giroud N (2007) New methods for the direct determination of dissolved inorganic, organic and total carbon in natural waters by Reagent-Free lon Chromatography and inductively coupled plasma atomic emission spectrometry. Anal Chim Acta 582: 69-74.

15. Mermet JM (2005) Is it still possible, necessary and beneficial to perform research in ICP-atomic emission spectrometry? J Anal Atom Spec 20: 11-16.

16. New Jersey Clean Air Council (2004) Annual Public Hearing Report Clean Air Council. Fine particulate matter in the atmosphere - Health Impacts in NJ- Need for Control Measures 330.

17. Ramgolam K, Chevaillier S, Marano F, Baeza-Squiban A, Martinon L (2008) Pro inflammatory effect of fine and ultrafine particulate matter using size-resolved urban aerosols from Paris. Chemosphere 72: 1340-1346.

18. Yatkin S, Bayram A (2008) Determination of major natural and anthropogenic source profiles for particulate matter and trace elements in Izmir, Turkcya. Chemosphere 71: 685-696.

19. Yatkin S, Bayram A (2007) Elemental composition and source of particulate matter in the ambient air of a Metropolitan City. Atmospheric Res 85: 126-139.

20. Hauck H (1998) Revision of ambient air quality standards for PM? Toxicol Lett 96-97: 269-76.

21. Barceloux DG (1999) Copper. J Toxicol Clin Toxicol 37: 217-230.

22. State of Ohio Environmental Protection Agency (2002) Copper and Copper Compounds. Pollution Prevention Fact Sheet 92: 644-3469.

23. Hoffmann P, Dedik AN, Ensling J, Weinbruch S, Weber S, et al. (1996) Speciation of Iron in atmospheric aerosol samples. J Aerosol Sci 21: 325-337.

24. Spokes L, Jickells T, Jarvis $K$ (2001) Atmospheric inputs of trace metals to the northeast Atlantic Ocean: the importance of southeasterly flow. Marine Chem 76: $319-330$

25. Viana M, Querol X, Alastuey A, Ballester F, Llop S, et al. (2008) Characterising exposure to PM aerosols for an epidemiological study. Atmospheric Environ 42: $1552-1568$

26. Agency for Toxic Substances and Disease Registry (1997) US Public Health Service. ATSDR's Toxicological Profiles: Copper. Lewis Publishers, CRC Press Inc, Boca Raton, Florida.

27. Davies DJ, Bennett BG (1985) Exposure of man to environmental copper-an exposure commitment assessment. Sci Total Environ 46: 215-227.

28. Weant GE (1985) Sources of Copper Air Emissions. Research Triangle Park, North Carolina: Air and Energy Engineering Research Laboratory, US Environmental Protection Agency (EPA), 600/2-85-046.

29. Schroeder WH, Dobson M, Kane DM, Johnson ND (1987) Toxic trace elements associated with airborne particulate matter: A review. J Air Pollut Control Assoc 37: 1267-1285

30. Jaradat QM, Momani KA (1999) Contamination of roadside soil, plants, and ai with heavy metals in gordan, a cooparative study. Turk J Chem 23: 209-220. 